\title{
Accidental Cymoxanil (TANOS) pesticide poisoning (Case report)
}

F. Sasvary ${ }^{1,2}$, M. Supinova $a^{1,2}$

${ }^{1}$ Internal Department, General Hospital, Sahy, Slovakia

${ }^{2}$ Faculty of Health Slovak Medical University in Bratislava located in Banska Bystrica, Slovakia

\section{Correspondence to:}

Internal Department, General Hospital, Sahy, Slovakia, Hontianska cesta, 93601 Šahy, Slovakia, e-mail: sasvary69@gmail.com.

Submitted: 15.6.2016 Revised: 23.8.2016 Accepted: 6.9.2016

\section{Reviewers:}

K. Kralinsky

Children‘s Faculty Hospital Banska Bystrica, Námestie Ludvika Svobodu 4, 97409 Banská Bystrica, Slovakia

S. Subramanian

SAAaRMM, Kuala Lumpur, Malaysia

\section{Key words:}

Pesticide, Cymoxanil, Poisoning.

\section{Key message}

Unsual case of a poisoned child.

CSWHI 2016; 7(3): 27-31; 10.22359/cswhi_7_3_07 @ 2016 Clinical Social Work and Health Intervention

\section{Abstract:}

Background: Pesticides are a group of chemicals used in agriculture in order to achieve higher and better-quality crops. The vast majority of these are synthetic substances whose effect on the human organism is unfavorable, even toxic.

Methods: We provide a brief overview of available Slovak and world literature on these issues. In the next section, we deal with the case of a patient, whose leading symptoms were headache and behavioral changes. After excluding organic lesions, we made a diagnosis ,per exclusionem" and diagnosed cymoxanil poisoning.

Conclusions: We consider the relatively low number of recorded poisonings to be a result of strict regulation of pesticide use. 


\section{Introduction}

Pesticides are chemicals used to protect vegetables against animal pests, fungi and weeds. These are organic or inorganic substances. They are applied as a spray, powder, granules or mordant. The most important pesticides are insecticide substances used for destroying insects; fungicides - substances used to destroy harmful parasitic fungi; herbicide substances used for weed control; rodenticides - substances used for destroying rodents ${ }^{1}$. (1)

If one uses pesticides it is important to work with extreme caution. How to use them and health at work are regulated by provisions having the force of $\operatorname{law}^{2,3} \cdot(2-3)$

TANOS 50WG is a combined two-component fungicide to protect potatoes against potato blight and potato Alternaria leaf spot, tomatoes against potato blight; cucumbers and zucchini against cucumber Peronospora; vines against Peronospora. Active substance: cymoxanil $250 \mathrm{~g} / \mathrm{kg}+$ famoxadone $250 \mathrm{~g} / \mathrm{kg}$. Formulated as: dispersible granule Mechanism of action: systemic and contact.

Antracol Combi WP 76 is a combined two-component fungicide intended for plant care, with a spectrum of activity similar to the product TANOS 50WG. Active substance: propineb $70 \%+$ cymoxanil $6 \%$. Formulated as: dispersible powder ${ }^{4}$.

Characterization of cymoxanil: Chemical characterization: N-ethylaminocarbonyl-2-cyano-2-methoxyiminoacetamide. The substance belongs to the class of acylureas. It acts primarily in systemic, but partly also in contact, fashion on plants. The effects of cymoxanil in plants include inhibition of nucleic acid synthesis, reduction in the permeability of cell membranes, limiting respiration and disruption of serine, glycine and cysteine synthesis. This results in inhibition of mycelial growth, reduction of sporulation and spores germination ${ }^{5}$.

Symptoms of cymoxanil poisoning are presented in Table 1.

\section{Case description}

A 50-year-old, otherwise healthy man was brought into the internal medicine emergency room with a headache lasting 4 days and body temperature up to $38^{\circ} \mathrm{C}$. Beside the headache he complained about dry mucous membranes of the mouth, loss of appetite, fatigue, increased sweating, also at night. Targeted questions specified that four days before admission, i.e. before symptoms started, he sprayed vegetables against fungi. He could not specify the product name. During the spraying he was exposed to direct sunlight and despite knowledge of safety he did not use any respirator.

The symptoms started the next morning and persisted during the consultation with a doctor.

Objective finding reads that the patient was obese (BMI 33), skin was sweaty, body temperature $36.5^{\circ} \mathrm{C}$, isocoric pupils in middle position, bulbs without nystagmus, injected conjunctiva. Overall, psychomotor restlessness was present. The patient was restless \& fussed to find a relief position. Neither neurological focality nor laterality were observed. Signs of meningeal irritation were indicated. The laboratory tests showed neutrophilic leukocytosis, adequate coagulation parameters, a high level of C-reactive protein, a normal procalcitonin, slightly increased GMT activity (Table 2).

CT scan of the brain + skull trauma program were indicated. The finding was negative.

The condition was evaluated as susp. Meningitis. We indicated parenteral antibiotic therapy. We examined the eye-ground with age-appropriate findings. The patient was IV hydrated and orally hydrated at the same time. During hospitalization the body temperature repeatedly exceeded $38^{\circ} \mathrm{C}$, we took a blood culture but it was completed with negative results. 
Family members delivered packaging of the spraying used. It was a TANOS preparation (active substances: cymoxanil + famoxadone). From the available literature we found that symptoms may indicate a cymoxanil poisoning.

Tests for focal infection were conducted. Echokg, dental and ENT findings were normal. The eyeground finding was negative.

Hydration, antibiotic, anti-edematous (mannitol) and analgesic treatment continued. The patient's condition gradually improved. On the fifth day he was in good condition released to outpatient care.

\section{Discussion}

In available Slovak and world literature there is a minimum of described cases of accidental pesticide poisoning. Searching through Medline, apart from two case reports, we found only descriptions of the results of laboratory experiments and monitoring of workers ${ }^{6,7,8} \cdot(6-8)$. There are mainly articles describing the effects of these substances in the laboratory or in experiments.

The low number of accidental poisonings may be a result of very strict regulatory measures which the workers with pesticides are obliged to observe ${ }^{9}$.(9). In the USA, for the period from 1988 to $2005,3,271$ cases of pesticide poisoning were recorded. Of these, 20 were severe ${ }^{10}$. Unfortunately, we could not find data from the Slovak Republic.

The diagnosis of ,poisoning Cymoxanil" was determined per exclusionem, after excluding other possible diseases such as meningitis, focal infection, disruption of the internal environment, CNS tumor or stroke. (10-11). From the available literature, we found that there is no specific treatment for cymoxanil poisoning. We followed the recommendations and the patient was administered supportive, anti-edematous and eliminating treatment.

\section{Conclusion}

Using only products which are mentioned in the list of registered and permitted pesticides $^{11}$ and using the prescribed personal protective means virtually eliminates the possibility of damage to human health.

The poisoning, also described in this case, occurred due to a failure to observe safety measures - to use personal protective equipment.

Authorship contributions: authors contributed equally to preparing the manuscript

Conflict of interest statement: The authors state that there are no conflicts of interest regarding the publication of this article.

\section{References}

1. KEGLEY SE, HILL BR, ORME S, Choi AH: PAN Pesticide Database, Pesticide Action Network, North America (Oakland, CA, 2014). Available from: http:www.pesticideinfo.org

2. Act of the National Council of the Slovak Republic No. 405/2011 Coll. on Phytosanitary Care (In Slovak)

3. Ministry of Agriculture and Rural Development of the Slovak Republic. The National Action Plan to Achieve the Sustainable Use of Pesticides. (in Slovak) Available from: http://www.mpsr.sk/index. php?start\&navID=1\&id=6985

4. HAYES WJ Jr., LAWS ER Jr., Editors. Handbook of Pesticide Toxicology. Volume 2. Classes of Pesticides. New York, NY: Academic Press, Inc., 1991.

5. PHYTOPATHOLOGY BASICS. Katedra botaniky Př́rodovědecká fakulta UP v Olomouci. (In Czeck) Available from: http:// isb-up.cz/data/PDF/ZFP/Zaklady-fytopatologie-7.pdf

6. TITLIC M, JUKIC I, TONKIC A, PUNDA A: Headache caused by handling the pesticide Antracol Combi WP 76: a case report. 
J Headache Pain. 2007;8(6):345-7. Epub 2007 Dec 10.

7. KOCH P: Occupational allergic contact dermatitis and airborne contact dermatitis from 5 fungicides in a vineyard worker. Cross-reactions between fungicides of the dithiocarbamate group? Contact Dermatitis. 1996;34(5):324-9.

8. HOYOS LS, CARVAJAL S, SOLANO L, RODRIGUEZ J, OROZCO L, LOPEZ Y, $\mathrm{Au}$ WW. Cytogenetic Monitoring of Farmers exposed to pesticides in Colombia. Environ Health Perspect 1996;104 Suppl 3:535-8.

9. DAVANZO F, SETTIMI L, FARAONI L, MAIOZZI P, TRAVAGLIA A, MARCELLO I. [Agricultural pesticide-related poisonings in Italy: cases reported to the Poison
Control Center of Milan in 2000-2001].(In Italian) Epidemiol Prev. 2004;28(6):330-7.

10. CALVERT GM, KARNIK J, MEHLER L, BECKMAN J, MORRISEY B, SIEVERT J, BARRETT R, LACKOVIC M, MABEE L, SCHWARTZ A, MITCHELL Y, MORAGA-McHALEY S: Acute pesticide poisoning among agricultural workers in the United States, 1998-2005. Am J Ind Med. 2008;51(12):883-98.

11. SILHAROVA B, SUVADA J, FRANEKOVA M, NOGE A, MIKOLASOVA G: Malaria in hyperendemic region, Neuroendcrinology Letters 34, 2013, s1 38-43

12. KEIFER M, GASPERINI F, ROBSON M.: Pesticides and other chemicals: minimizing worker exposures. J Agromedicine. 2010;15(3):264-74.

Tab. 1 Symptoms of cymoxanil poisoning

\begin{tabular}{ll}
\hline Mild & eye irritation, allergic skin exanthema \\
\hline Moderate & headache, nervousness, visual impairments, asthenia, nausea, muscle \\
& cramps, diarrhea, discomfort in the chest, miosis, sialorrhoea, gasping, \\
& vomiting, cyanosis \\
\hline Severe & convulsions, disturbance of consciousness up to coma, hyporeflexia up to \\
& areflexia, plegia of sphincters, cardiac arrhythmia, cardiac arrest \\
\hline
\end{tabular}


Tab 2 Lab test values of the patient

\begin{tabular}{|c|c|c|c|c|}
\hline Parameter & Unit & 04.07 .2015 & $05.07 .2015 \quad 06.07 .2015$ & 07.07 .2015 \\
\hline FW & $\mathrm{mm}$ & & $12 / 20$ & \\
\hline \multicolumn{5}{|l|}{ Blood count } \\
\hline Leucocytes & $10^{3} / \mathrm{uL}$ & 15.5 & & 14.2 \\
\hline Erythrocytes & $10^{6} / \mathrm{uL}$ & 5.21 & & 4.13 \\
\hline Haemoglobin & $\mathrm{g} / \mathrm{L}$ & 164 & & 130 \\
\hline Hematocrit & ratio & 0.46 & & 0.38 \\
\hline Thrombocytes & $10^{3} / \mathrm{uL}$ & 204 & & 171 \\
\hline \multicolumn{5}{|l|}{ Coagulation } \\
\hline PT & INR & 1.23 & 1.22 & \\
\hline aPTT & ratio & 1.11 & 1.08 & \\
\hline Fibrinogen & $\mathrm{g} / \mathrm{L}$ & 2.43 & 2.38 & \\
\hline D-dimer & $\mathrm{ug} / \mathrm{ml} \mathrm{FEU}$ & 0.27 & & \\
\hline \multicolumn{5}{|l|}{ Biochemistry } \\
\hline Glucose & $\mathrm{mmol} / \mathrm{L}$ & 7.47 & & \\
\hline Urea & $\mathrm{mmol} / \mathrm{L}$ & 7.3 & & 3.4 \\
\hline Creatinine & umol/L & 124 & & 110 \\
\hline Uric acid & umol/L & 485 & & \\
\hline Proteins & $\mathrm{g} / \mathrm{L}$ & 81.7 & & 67.2 \\
\hline Albumin & $\mathrm{g} / \mathrm{L}$ & 49.9 & & 41.5 \\
\hline Total bilirubin & umol/L & 23.4 & & 9.6 \\
\hline Dir. bilirubin & umol/L & 3.8 & & \\
\hline AST & ukat/L & 0.32 & & 0.21 \\
\hline ALT & ukat/L & 0.59 & & 0.40 \\
\hline GMT & ukat/L & 1.38 & & 1.03 \\
\hline ALP & ukat/L & 1.08 & & 0.95 \\
\hline Cholinesterase & ukat/L & 215.14 & & \\
\hline Cholesterol & $\mathrm{mmol} / \mathrm{L}$ & 6.01 & & 4.31 \\
\hline HDL-Chol & $\mathrm{mmol} / \mathrm{L}$ & 0.77 & & 0.77 \\
\hline LDL-Chol & $\mathrm{mmol} / \mathrm{L}$ & 3.01 & & \\
\hline Triglycerides & $\mathrm{mmol} / \mathrm{L}$ & 2.66 & & 2.66 \\
\hline AMS & ukat/L & 0.72 & & \\
\hline Natrium & $\mathrm{mmol} / \mathrm{L}$ & 132.3 & & 138.7 \\
\hline Kalium & $\mathrm{mmol} / \mathrm{L}$ & 4.2 & & 4.0 \\
\hline Calcium & $\mathrm{mmol} / \mathrm{L}$ & 2.56 & & 2.2 \\
\hline Chlorides & $\mathrm{mmol} / \mathrm{L}$ & 97.2 & & 101.9 \\
\hline Phosphorus & $\mathrm{mmol} / \mathrm{L}$ & 0.85 & & 0.99 \\
\hline Magnesium & $\mathrm{mmol} / \mathrm{L}$ & 0.97 & & 0.98 \\
\hline CRP & $\mathrm{mg} / \mathrm{L}$ & 1.1 & & 73.7 \\
\hline Procalcitonin & $\mathrm{ng} / \mathrm{mL}$ & under cut-off & & under cut-off \\
\hline Troponin I & $\mathrm{ng} / \mathrm{mL}$ & under cut-off & & \\
\hline NT-pro-BNP & $\mathrm{pg} / \mathrm{mL}$ & under cut-off & & \\
\hline $\operatorname{IgE}$ & $\mathrm{IU} / \mathrm{mL}$ & 136.6 & & \\
\hline
\end{tabular}

